\title{
MALE AND FEMALE PATTERNS OF LABOUR FORCE PARTICIPATION: A COMPARISON BETWEEN FRANCE AND JAPAN
}

\author{
Hiroatsu Nohara* \\ * Laboratory of Labour Economics and Industrial Sociology, (LEST-CNRS), \\ Aix-Marseille University, Aix-en-Provence, France
}

\begin{abstract}
Article published in Marc Maurice and Arndt Sorge eds. Embedding Organizations: Societal Analysis of Actors, Organisations and Socio-economic Contexts, Johon Benjamins Publishing Company, Amsterdam and Philadelphia. 2000. pp373-388.
\end{abstract}

\begin{abstract}
This article seeks to compare the patterns of articulation - in France and Japan - between the men's activity and women's activity in the society. In particular, we focus on the differences of activity models between French and Japanese women, which can be considered as a good analyser to reveal a specific - and national - form of interdependence between work, family and society. Based on the descriptive macro-statistic method, we aim to show that the national model of women's activity doesn't originate purely neither from the individual rational choice - cost/advantage calculation within the household nor from the national culture domination. We posit that such a model is a social 'fabric' which is constructed on the interaction between the strategic interplay of various actors and the national representation of family crystallized in the public social policies.
\end{abstract}

\section{Résumé}

Ce texte se propose de comparer, entre la France et le Japon, les modalités d'articulation des activités des femmes et des hommes dans la société, en particulier en mettant l'accent sur la comparaison des modèles d'activité féminine qui s'avèrent comme un analyseur pertinent de l'interdépendance entre travail, famille et société. Basé sur la méthodologie du type macro - statistique, il vise à montrer que le modèle "national" d'activité féminine ne résulte ni simplement d'un choix fondé sur le calcul coût - avantage au sein du ménage considéré comme un espace de capital, ni d'une culture nationale omnipotente, mais qu'il se construit sur une interaction entre les jeux d'acteurs stratégiques et la représentation de la famille cristallisée autour des politiques des pouvoirs publics. Cet arbitrage au sein du ménage, qui n'exclue pas forcément le calcul, s'effectue néanmoins dans un espace fortement structuré non seulement par la tradition culturelle mais aussi et surtout par les sociétales

forgées

différemment

d'une

société

à

l'autre. 
This article seeks to examine the differences in the way in which male and female patterns of labour force participation in France and Japan are articulated over the life cycle. To this end, our analysis will focus on the modes of societal regulation of gender relations, and in particular on a comparison of the forms of female labour force participation that seem to constitute a practicable indicator of the interdependencies between work, family and society. A great deal of research into female labour force participation has been carried out in France in recent years, particularly from a European comparative perspective (O. Benoit - Guilbot 1987, L. Hantrais and M-T. Letablier eds. 1995). This research has revealed the wide diversity of national situations, despite the existence of certain universal basic trends, such as the increase in female participation rates over time, the occupational distribution of women's jobs, etc. This finding provides support for our basic hypothesis that female labour force participation is a "social construct" specific to each society and involving interaction between a multiplicity of different dimensions, including education, occupational structures, the family and the state (public policies). Thus female labour force participation, particularly viewed from the perspective of its interdependence with male patterns of work, is a useful tool for analysing the way in which a society conceives of social justice and organises the articulation between the economic and social spheres.

Having thoroughly surveyed the existing literature, we will take these earlier studies as our starting point while at the same time extending the scope of our analysis to include Japan, a country comparable in economic terms to France but outside the European cultural and historical sphere. Unlike most of these earlier studies, however, we will not confine ourselves to comparison of patterns of female labour force participation but will take into account a more general analysis of the (social and occupational) forms of gender relations. Only by adopting such a perspective, it seems to us, can the way to a full understanding of the interrelated systems that produce the various forms of "societal coherence" be truly opened up.

In other words, by constructing a few simple indicators and comparing them systematically, we are seeking to reveal the multiplicity of differences between the two countries in the way in which men and women are integrated into society and the labour market. However, the differences revealed by a term-for-term comparison will have no significance beyond their mere factuality. They will not have any real meaning, or provide any real interpretative clues, unless they are relocated in the context and logic of the internally consistent national systems in which they find their legitimacy (M. Maurice, F. Sellier, J.-J. Silvestre 1986). This concept of social phenomena leads us to adopt an interpretative framework that aims to link several levels of analysis simultaneously: individual/family strategy, firms' HRM practices and public policy measures. The interaction between these three levels in each country produces the nationally dominant form of labour supply.

Our working hypothesis is that "national models of female labour force participation" are not simply the result of choices based on cost-benefit analyses carried out by individual households as if they were firms operating in the capitalist economy (G. Becker 1964) or of an omnipotent national culture, but that they are constructed through the interaction between the actions of strategic actors and the notion of the family that crystallises around the policies adopted by national governments. Thus the settlements made at household level (family division of labour), which in no way exclude cost-benefit analyses, are concluded in a space that is highly structured not only by cultural traditions (family model) but also by state mechanisms which, forged over time, differ by definition from one country to another.

In order to put our statements to the test, we will carry out a number of descriptive statistical analyses. Since we have adopted a methodology of the macro-statistical type, the quality of our analyses will be determined by the reliability of the various bodies of statistical data. Statistical data are available for both of the countries of interest to us here, in particular those gathered during the national employment surveys conducted among households ${ }^{1}$. It is true that these surveys are not strictly comparable: the data gathering methods are slightly different, while the definitions of the statistical categories reflect the differences between the representational and referential systems of the two countries. However, they both aim to capture in the broadest possible way the twin concepts of work and non-participation. In particular, they have the merit of being based not on categories constructed ex post but rather on the unprompted statements of the individuals surveyed. Thus these data are derived from the opinions of those directly concerned. There is occasionally a risk that the subjective and objective will be confused, but the surveys have proved well suited to analysis of the female population, for whom it can be genuinely difficult to define clearly the boundaries between participation, non-participation and unemployment.

This article will deal, firstly, with the statistical problems relating to the working population. The second part will deal with the characteristic features of female labour force participation; in particular, part-time work will be used as the indicator best suited to revealing the societal nature of the settlements made in individual households. This analysis will make it possible to identify two forms of "family convention" established in France and Japan. In the third section, we will identify two forms of "wage-labour convention" by analysing men's and women's career trajectories and the differentiation of their wage

\footnotetext{
1 In the case of France, the data are derived from the "employment survey" carried out annually by INSEE among 70,000 households and, in the case of Japan, from the "Employment Status Survey" carried out every 5 years among 42,000 households by the Prime Minister's statistical office.
} 
curves from phase to phase of the life cycle. By way of conclusion, we will return to the interdependent relationships between these two conventions in order to examine the societal approach.

\section{THE AMBIGUOUS NOTIONS OF ECONOMICALLY ACTIVE POPULATION AND UNEMPLOYMENT}

The two 1992 employment surveys allow us to measure the size of the economically active population and then to examine the boundaries between labour force participation, non-participation and unemployment in the two countries. The criteria adopted here are based on the unprompted responses given to filter questions designed to discover how the interviewee defines him/herself at the time of the survey, irrespective of what he/she did during the reference period. This statistical convention, thus defined, classifies and quantifies the various categories shown in Table 1.

The notion of economically active population, captured without further refinement in these surveys, reflects in part the need in each economy to measure its human resources. In these strictly quantitative terms, Japan has at its disposal two and a half times the human resources available to France.

Furthermore, a greater share of the Japanese population is involved in the production of national wealth, particularly in the older age groups. Similarly, the lower unemployment rate in Japan suggests that the available resources are mobilised more effectively than in France (the unemployment rate is $14.2 \%$ for women and $8.7 \%$ in France, compared with $8.0 \%$ for women and $2.1 \%$ for men in Japan). On the macroeconomic level, therefore, France is characterised by the underutilisation of labour, which is associated with a low level of employment, whereas Japan is more or less at the point of equilibrium, since unemployment there can be regarded as "natural" or "frictional" if judged by an international norm of the ILO kind.

TABLE 1

COMPARISON BETWEEN FRANCE AND JAPAN, 1992 (in 000s)

\begin{tabular}{|c|c|c|c|c|}
\hline & & Total & Women & Men \\
\hline \multirow{7}{*}{ FRANCE } & $\begin{array}{l}\text { Population of working age } \\
\text { (15-64 years) }\end{array}$ & 3719 & 1871 & 1848 \\
\hline & $\begin{array}{ll}\text { Economically } & \text { active } \\
\text { population } & \end{array}$ & 2495 & 1112 & 1383 \\
\hline & $\begin{array}{l}\text { Unemployed individuals } \\
\text { seeking work }\end{array}$ & 278 & 158 & 120 \\
\hline & $\begin{array}{l}\text { Economically inactive } \\
\text { population (fig. In brackets: those } \\
\text { wishing to work) }\end{array}$ & $\begin{array}{l}1224 \\
(37)\end{array}$ & $\begin{array}{l}759 \\
(25)\end{array}$ & $\begin{array}{l}465 \\
(12)\end{array}$ \\
\hline & $\begin{array}{ll}\text { Participation rate } & (\%)\end{array}$ & 67.1 & 59.4 & 74.8 \\
\hline & $\begin{array}{ll}\text { Unemployment rate } & (\%)\end{array}$ & 11.1 & 14.2 & 8.7 \\
\hline & ILO unemployment rat $(\%)$ & 10.1 & 12.8 & 7.9 \\
\hline \multirow{7}{*}{ JAPAN } & $\begin{array}{l}\text { Population of working age } \\
\text { (15-64 years) }\end{array}$ & 8670 & 4329 & 4341 \\
\hline & $\begin{array}{ll}\text { Economically } & \text { active } \\
\text { population } & \end{array}$ & 6437 & 2750 & 3687 \\
\hline & $\begin{array}{c}\text { Unemployed individuals } \\
\text { seeking work }\end{array}$ & 299 & 221 & 78 \\
\hline & $\begin{array}{l}\text { Economically inactive } \\
\text { population (fig. In brackets: those } \\
\text { wishing to work) }\end{array}$ & $\begin{array}{l}2233 \\
(439)\end{array}$ & $\begin{array}{l}1579 \\
(391)\end{array}$ & $\begin{array}{l}654 \\
(48)\end{array}$ \\
\hline & Participation rate & 74.4 & 63.6 & 85.2 \\
\hline & Unemployment rate $\quad$ (\%) & 4.6 & 8.0 & 2.1 \\
\hline & ILO unemployment rate $(\%)$ & 2.2 & 2.4 & 2.1 \\
\hline
\end{tabular}

Source: 1992 Employment Survey, INSEE, France and 1992 Employment status survey, Management and Coordination Agency, Japan 
Since the overall differences are significant, a characterisation of this kind clearly reveals, in quantitative terms, the features specific to each national economy. However, any attempt at quantification also has its limits as a means of capturing the sociological state of the economically active population.

These limits can be illustrated by reference to the ambivalence surrounding the definitions of labour force participation, non-participation and unemployment. Comparison between the unemployment rate as measured by unprompted statements and that measured in accordance with the ILO definition ${ }^{2}$ reveals more or less pronounced gaps, in both France and Japan. The stricter ILO definition of unemployment tends to reduce the number of unemployed people in all countries, but especially in Japan. Here, the various statistical sources give pretty much the same figure for male unemployment. However, the number of unemployed women rises from 630,000 (the official unemployment figure according to the ILO definition in September 1992. Annual report on the labour force) to 2,210,000 (Employment survey of October 1992 , based on unprompted statements), which represents a tripling of the female unemployment rate from $2.4 \%$ to $8.0 \%$. A gap of this magnitude, which depends largely on whether or not "availability for work" is taken into account, suggests a certain degree of ambivalence among Japanese women in their attitude towards job-seeking. In fact, women's situation is even more complex: according to the same survey, 3,910,000 Japanese women who are not economically active $(24.7 \%$ of the total non-working population of $15,790,000$ ) would like to work if they had the opportunity to do so. This enormous number of women, most of whom are housewives, retain the desire to work without actually seeking employment or being immediately available. This latent labour supply, which nevertheless has little in common with the classic notion of "hidden unemployment", accurately reflects the specific characteristics of women's position in Japanese society. From the point of view of the labour market, it is as if there were no disjunction between various states of availability and the opportunity to enter paid employment. The effect of this is to create a certain degree of adaptability, since a not insignificant share of women may well move across the boundaries between economic activity, inactivity and unemployment as economic circumstances change.

This type of phenomenon is not wholly unknown in France, but it seems to be much more limited in scope among both women and men. Thus, non-economically active people who would like to work account for only $3 \%$ of the noneconomically active population. In general, there is a high degree of concordance in France between statistical definitions and the self-ascribed status of individuals, who tend to internalise the principles underpinning the administration of the labour market ${ }^{3}$; in Japan, on the other hand, there is some degree of statistical ambiguity which reflects not so much a problem with technical definitions but rather a certain sociological ambivalence in attitudes to employment.

\section{THE CONSTRUCTION OF THE LABOUR SUPPLY OVER THE LIFE CYCLE IN FRANCE AND JAPAN}

This outline of the major characteristics of the economically active population has led us to emphasise the relative nature of this category as a country-specific "social construct". Bearing this relativity in mind, we will now examine the ways in which the male and female labour supply is constructed over the life cycle. We shall be seeking to discover how the various life events exert a differential influence on the commitment of men and women to economic activity; our main analytical tool will be participation rates, an indicator often used in international comparisons. Figure 1 shows both the trends that are common to both countries and a few noteworthy differences in the patterns of male and female labour market behaviour.

As far as the common trends are concerned, there are two main phenomena to be noted. Firstly, participation rates in all age groups are higher (or at least the same) among men than among women. Secondly, the unemployment rate (unemployed individuals actively seeking a job) is consistently lower among men than among women.

However, these general truths find concrete expression in extremely heterogeneous societal contexts, which create specific forms of articulation between male and female patterns of economic activity. The first thing to note is that societal differences are most marked at either end of the working life, and are closely associated with institutions such as the education and pension systems.

The early stages of young people's working lives are organised differently in France and Japan. In France, where there is a shortage of jobs, young people experience a certain degree of difficulty in entering the labour market, although the

\footnotetext{
${ }^{2}$ According to the ILO definition, a person is in employment if he or she actually worked, if only for one hours, in the course of the reference week. On the other hand, he/she is unemployed if he/she did not work during the same week, if he/she is available for week in the next two weeks and he/she is actively seeking work.

${ }^{3}$ Among unemployed job-seekers, $89 \%$ in France stated they were registered with the employment service, compared with only $16 \%$ in Japan. In Japan, the way in which "actively seeking employment" is defined in itself raises difficult interpretative problems.
} 
difficulties encountered vary according to qualifications and gender. At the same time, there is now a trend for them to remain in education well beyond the

\section{FIGURE 1 - PARTICIPATION AND UNEMPLOYMENT RATES}

\section{MEN}

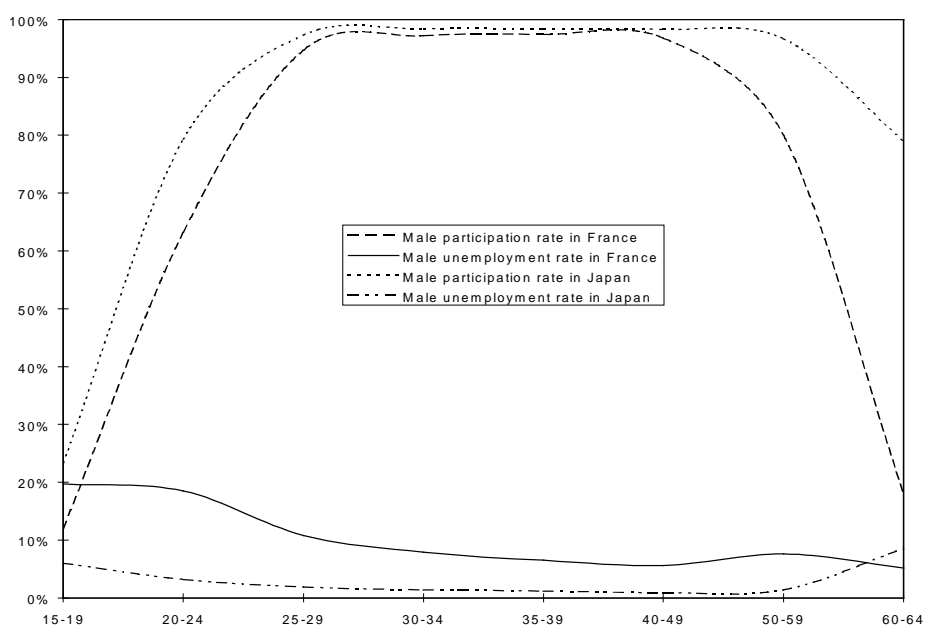

WOMEN

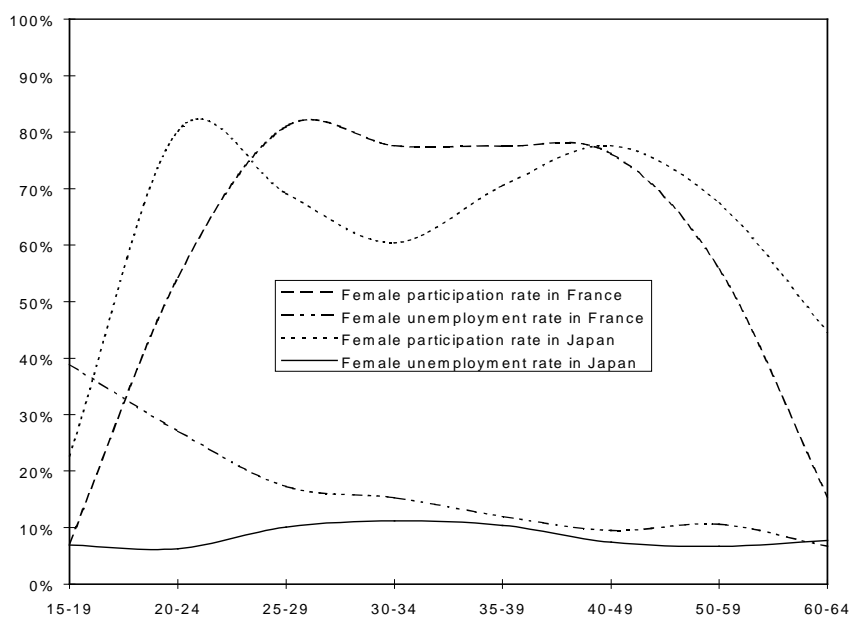

baccalauréat, which delays their entry into the labour market even further. As a result, France has one of the highest rates of youth unemployment and enrolment in education in the OECD. ${ }^{4}$ In Japan, the transition from school to work appears to be relatively unproblematic, and youth unemployment rates are fairly low, regardless of qualifications and gender. The employability of girls and young women does not seem to be harmed by the gender segregation in schools, which is more marked than in France. As well as the difference in rates of access to higher education, boys tend to opt for the longer courses (4 years or more), while most girls choose the shorter, 2-year, non-vocational courses, many of which were originally intended to provide training in "domestic science".

At the other end of the working life, retirement is also organised differently in the two countries, despite the fact that the nominal retirement age is 60 in both countries. In France, only a small minority of people remain in employment after the age of 60 (15\% of women and $18 \%$ of men in the $60-64$ age group). This trend is further reinforced by the increasing use of early retirement in response to recession. In Japan, $45 \%$ of women and $79 \%$ of men are still economically active between the ages of 60 and 64. Many older people seek to delay their final retirement, even though their labour market status might deteriorate. These enormous differences in the various societal factors (education, labour market entry and retirement) can obviously not be dissociated from the way in which each society conceives of the relationship between wealth creation and its own reproduction.

However, such problems lie well outside the scope of this chapter. Our attention here is to focus on the hard core of the economically active population between the ages of 25 and 60 . Even when restricted to this category, which tends to be well integrated into the labour market, comparison of male and female patterns of labour force participation reveals some significant differences. In general terms, the various differences between men and women are considerably less marked in France than in Japan, whether in terms of unemployment or the evolution of participation rates. As in all countries, of course, male participation rates are very close to the maximum in both countries. Despite this similarity, however, levels of male unemployment differ considerably from one country to the other; Japanese men are very highly integrated into the productive system, while a segment of the French male population aged $25-60$ seems to be in a permanently precarious position in the labour market.

The position of women in the two countries diverges considerably. ${ }^{5}$ The evolution of participation rates among French women is relatively stable. Despite a relatively high unemployment rate, three quarters of them remain permanently in the labour market, a pattern of behaviour that is growing ever closer to the dominant male pattern. Participation rates for

\footnotetext{
4 The unemployment rate and the rate of enrolment in education among young people aged $20-24$ are $24.3 \%$ and $37.9 \%$ respectively in France, compared with $7.1 \%$ and $23.3 \%$ in Japan (source op. cit.).

5 The proportion of women in waged work is only $76.1 \%$ in Japan, compared with $87.4 \%$ in France. This difference is due to the fact that a not inconsiderable share of Japanese women are family workers. Although it is interesting, this difference will not be examined further in this chapter.
} 
Japanese women, on the other hand, fluctuate considerably, falling to a low of $60 \%$ in the child-bearing years between the two peaks of $80 \%$ in the $20-24$ age range and $78 \%$ among $40-49$ age group. These fluctuations reflect the cycle of withdrawal from and return to the labour market that is not unrelated to family events. At the same time, this discontinuity weakens their labour market position, as the high unemployment rate of more than $10 \%$ in the $25-39$ age group demonstrates.

From the point of view of societal analysis, the following points seem to be most significant: the pattern of female economic activity in Japan is characterised by the discontinuity dictated by family events, whereas the pattern of female economic activity in France is very close to - though not identical to, as we shall see - the male pattern, which in both Japan and France is virtually unaffected by domestic events. Thus family strategy in Japan, which is played out in a strictly private space, crystallises around a clear defined distribution of tasks between men and women. In France, various forms of state intervention tend to support women's labour market participation, while at the same time giving rise to complex strategic behaviour at household level. ${ }^{6}$ In the next two sections, we shall subject these hypotheses to greater scrutiny by examining, firstly, female participation rates in the light of responsibility for dependent children and, secondly, the problem of part-time work.

\section{II-1 Participation rates among women with children by mode of childcare}

It is already widely acknowledged that family circumstances, and in particular the number and age of children, have a greater or lesser influence on women's economic activity. However, these links between the family and female labour force participation are far from being the same in all countries; rather, they seem to be mediated by a whole range of institutional factors, which clearly reveal, moreover, the nature of the "family convention" within which the place of the family in society is defined.

In France, women's labour force participation remains relatively constant, irrespective of their responsibilities, until the arrival of the third child precipitates their withdrawal from the labour market. This event, which is closely connected with a long-established government policy that seeks to encourage a rising birth rate, marks a very definite break. On the other hand, the vast majority of French women with children remain economically active after having a second child, whatever the age of their youngest child. This pattern of behaviour, which varies, it is true, according to educational level, is not unconnected with the existence of institutional support mechanisms put in place in order to help women remain in the labour market. In particular, public day nurseries are now widely available, and free places in nursery schools are now offered to all children from age 3 onwards, with the result that $94 \%$ of children aged between 3 and 6 now attend nursery school (A-M Daune-Richard 1993). In Japan, the number of children plays little part in determining participation rates among women with children, or rather exerts a paradoxical influence. Unlike in most European countries, an increase in the number of children seems to encourage women to work outside the home. In conjunction with the absence of any explicit family policy, this phenomenon would seem to reflect the "private economic cost" of a child, which is very high, especially since the contribution made by the community is inadequate, particularly in respect of education costs. Thus one of the main factors in women's decisions to return to the labour market after a period of economic inactivity is a desire to obtain the resources needed to pay for children's education.

\section{TABLE II : EMPLOYMENT RATES AMONG MARRIED WOMEN (aged 15-49)} BY NUMBER AND AGE OF CHILDREN (under 18 years of age)

\begin{tabular}{|l|l|c|c|}
\cline { 3 - 4 } \multicolumn{2}{c|}{} & France $(\%)$ & Japan $(\%)$ \\
\hline \multirow{4}{*}{ No. of children } & No children & 71.4 & 66.3 \\
\cline { 2 - 4 } & 1 child & 69.7 & 53.3 \\
\cline { 2 - 4 } & 2 children & 65.7 & 60.7 \\
\cline { 2 - 4 } & More than 3 children & 35.7 & 62.3 \\
\hline \multirow{3}{*}{ Age of youngest child } & $0-2$ years of age & 51.0 & 28.2 \\
\cline { 2 - 4 } & $3-5$ years of age & 59.6 & 47.3 \\
\cline { 2 - 4 } & $6-17$ years of age & 66.0 & 69.1 \\
\hline
\end{tabular}

Source: op. cit.

\footnotetext{
${ }^{6}$ National divergence of the same kind have already been described by 0 . Benoit-Guilbot, whose starting point was a comparison of the structure of female unemployment in France and Great Britain. A certain degree of similarity emerges between Great Britain and Japan in the societal form of the regulation of gender relations, while France turns out to be an exception. It would be interesting to analyse this "similarity", since the historical contexts in the two countries in respect of industrialisation are diametrically opposed. Japan lagged far behind the European countries, particularly Great Britain, which was of course the pioneer of industrialisation.
} 
On the other hand, the age of the youngest child is a determining factor for the Japanese women in the cessation of economic activity, since only slightly more than one quarter of them with a very young child continue to work. The vast majority of Japanese women with a child under 3 years of age give up paid work except in very favourable circumstances, such as those prevailing in extended families when the grandparents are available to provide childcare. ${ }^{7}$ This systematic withdrawal from the labour market following the birth of the child is the cause of the fall in female participation rates in the 2534 age group. However, they re-enter the labour market as the child grows up. According to an estimate by the Ministry of National Education, fewer than $10 \%$ of young children aged between 0 and 2 are cared for in day nurseries, which are scarce and, above all, very expensive. At age $3,22.6 \%$ of children go to nursery school, most of which are private and expensive and close at 2.00 p.m., and $28.9 \%$ to municipal day nurseries, which are open until 5.00 p.m. but accessible only to children from households below a certain income threshold. At age $4,56.4 \%$ go to nursery schools and $32.3 \%$ to day nurseries; at age $5,63.8 \%$ go to nursery schools and $31.4 \%$ to day nurseries. Compulsory schooling starts at age 6 . However, unlike in France, where children remain in school until at least 4.30 p.m., school finishes very early, at 1.20 p.m. until age 8 and at 3.00 p.m. for older children. In other words, mothers' "social times" are subordinated to the schedules of the childcare infrastructure.

These great differences in institutional childcare arrangements between the two countries undoubtedly reflect their respective histories and even different ethnological concepts of the child (Joseishi kenkyukai (groupe d'étude sur l'histoire des femmes) 1993). ${ }^{8}$ In this sense, they represent a sort of social convention that crystallises in a very specific way in each society and strongly influences the way in which women construct their labour market participation. Far from being rigidly set, however, this social convention has the capacity to evolve over time, as is shown, for example, by the recent generalisation in Japan (1995) of "parental leave", which enables working mothers to take one year's leave on $25 \%$ of full pay. This is the first significant government measure to provide support for working women, and was certainly motivated by demographic concerns about the declining birth rate (1.50 in 1992).

\section{II-2 Part-time work as a tool for analysing the relationship between family and labour market}

In many OECD countries, the past twenty years have seen a considerable expansion of part-time work, which at the same time has given rise to a dispute about its true significance: is it a form of work freely chosen by individuals seeking to balance family responsibilities and paid work or a precarious form of employment that meets employers' needs for flexibility? France and Japan are two of the countries where part-time work has developed most rapidly, while at the same time tending to differentiate it clearly from the norm of "stable employment". However, this differentiation takes place against very different economic and societal contexts. By analysing it, we will hope to reveal the varying sets of principles underpinning the institutional arrangements in each society.

Again according to the same statistical sources, France has 2,390,000 part-time workers (12.8\% of wage-earners), of whom 2,034,000 are women, whereas Japan has 5,967,000 part-timers (11.3\% of wage-earners), of whom 5,639,000 are women. ${ }^{9}$ In both countries, therefore, part-time work is an overwhelmingly female phenomenon, with women accounting for $85.1 \%$ of part-timers in France and for $94.5 \%$ in Japan. Similarly, female part-timers account for $24.4 \%$ of all female wageearners in France and for $27.5 \%$ in Japan. However, these general quantitative similarities conceal significant differences between the two countries in the actuality of part-time work.

In France, where working mothers are supported by various publicly funded arrangements, part-time work seems to be neither a norm for women nor their preferred form of paid work. Once they have entered the labour market, French women tend to adopt the male pattern of labour market behaviour, irrespective of family events. In the public and other nonmarket sectors, for example, recourse to voluntary and reversible part-time work may very well reflect the preference of individuals seeking a better balance between family responsibilities and career. On the other hand, the expansion of parttime work since the 1980s, mainly in response to firms' flexibility requirements, mainly concerns unskilled women seeking work against a background of high unemployment. For the most vulnerable segment of the female labour supply, part-time work has become one of the means of getting into the labour market and, once in, staying in (A.-M. Daune-Richard,1993). Thus industries such as large-scale retailing and certain types of services use part-time work as a tool for managing both

\footnotetext{
${ }^{7}$ Households spanning three generations living under the same roof still represented $14 \%$ of all households at the beginning of the 1990s. This Japanese rate is reckoned very high by OECD standards.

8 In Japan, particularly strong emotional "bonding" between mother and child seems to make it psychologically difficult for women to entrust their very young children to the care of a third person. Irrespective of the economic cost, this mental state is said to be a constraint on the development of public care facilities for very young children.

${ }^{9}$ According to the labour forces survey, which defines part-time workers as those working fewer than 35 hours per week, there are $9,370,000$ part-timers in Japan ( $18 \%$ of wage-earners), $67 \%$ of whom are women.
} 
organisational flexibility and wage costs. In this case, part-time work becomes one of the forms of precarious employment and can no longer be considered voluntary.

\section{FIGURE II - The share of women working part time}

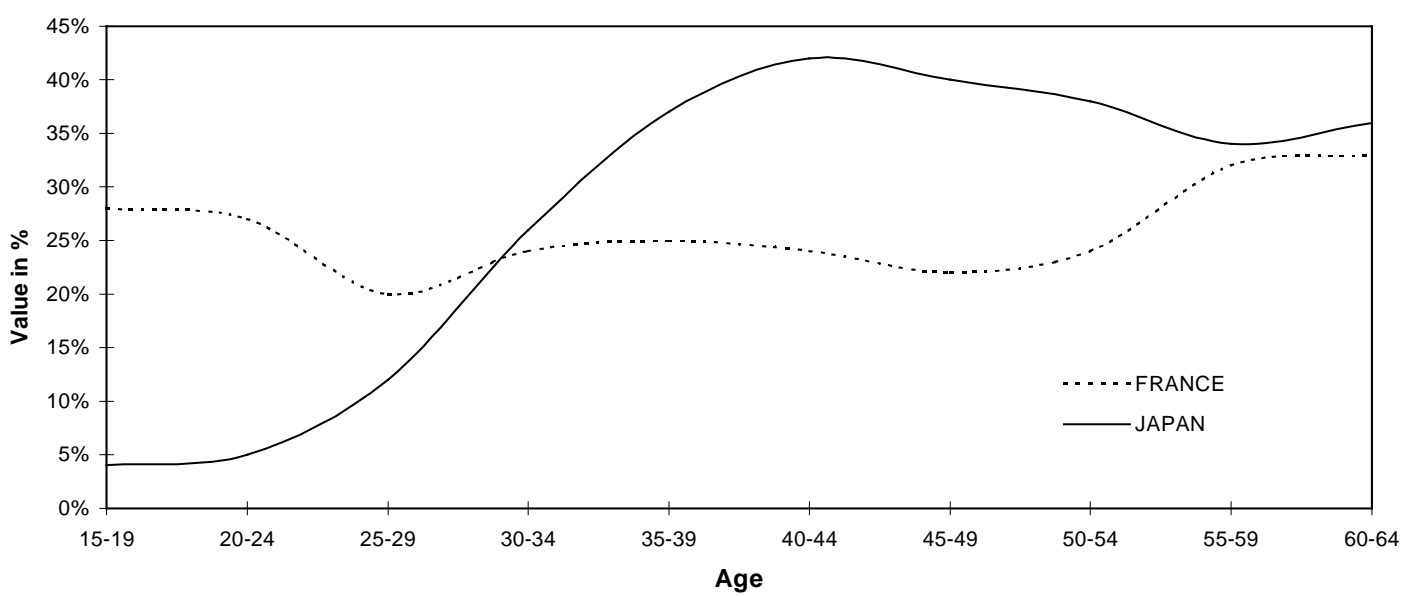

In Japan, as in France, part-time work tends to be associated with an "inferior" status to that of the "normal" fulltime worker on a permanent contract. Nevertheless, this "inferiority" operates according to different principles in the two countries. The share of female part-timers in total female employment in Japan, which is low up to the age of 29 , rises rapidly between the ages of 30 and 39 and stabilises after 40 at around $40 \%$ (see Figure II). This contrasts with the French situation, where age is not a differentiating factor in the choice of part-time employment, and indicates that part-time work in Japan is the employment form favoured by married women returning to the labour market after a longer or shorter period of absence during which they were bringing up their children. Here, part-time work is clearly associated with the status of working women as "wives and mothers". This connection between the status of women in the family and their place in the labour market, which is undoubtedly of cultural origin, is formalised and even consolidated by a range of incentive mechanisms. In addition to the arrangements for the care of young children, which encourage women to work shorter hours, various elements of social and fiscal policy have the effect of pushing women into part-time work:

1) The basis for the calculation of income tax liability is the household; a wife's earnings are considered as a secondary income and are completely exempt from tax up to a limit of 1.03 million yen. This threshold, which is quite high in view of the fact that median gross household income per annum was 5 million yen in 1992, encourages wives to keep their earnings - i.e. their labour supply - within this limit.

2) Under the terms of most collective agreements, couples receive a "housewife's allowance", which is a sort of family allowance paid by employers; it is worth on average between $£ 60$ and $£ 100$ per month, provided the wife's income does not exceed one million yen.

3) Wives and mothers whose annual earnings are lower than 1.3 million yen are exempted from social security contributions (health, retirement, unemployment etc.). Nevertheless, their status as "dependants" allows them to benefit from the social protection enjoyed by their husbands without making any specific contributions themselves, even though the cover ratio is slightly lower. Similarly, employers are not obliged to pay social security contributions (health and retirement insurance) for employees working part time (less than three-quarter time) and earning less than 1.3 million yen per year. They are also exempt from unemployment insurance contributions for employees working fewer than 22 hours per week and earning less than 900,000 yens per year.

Thus these social and fiscal arrangements buttress the Japanese model of the "housewife" whose labour market participation is subordinate to that of her spouse; in France, in contrast, women wishing to remain in continuous employment are actively supported in so doing. Paradoxically, these Japanese public policies, originally intended to provide protection for families, have helped to reinforce the segregation of wives and mothers from other groups of employees in the labour market and to marginalize the part-time jobs that serve as their points of re-entry into the labour market. 
Compared with French women in atypical jobs, who are explicitly protected by the various labour laws, the labour market position of Japanese women is indeed second-rate and weak. ${ }^{10}$ For example, $56 \%$ of Japanese women working part time are employed on fixed-term contracts of less than a year's duration, compared with $11 \%$ of female part-timers in France. In addition to the vulnerability created by the nature of the contract, short-term contracts of this kind make it difficult for working wives to gain access to the rights and benefits (bonuses, holidays, training etc.) enjoyed by permanent employees, even though many of them work long hours ( 26.8 hours per week on average and 4.8 years' seniority). ${ }^{11}$ This marginalisation is further reinforced by the fact that the minimum hourly wage (which is national and applicable to all sectors, although the actual rate varies by administrative district) is fixed at low levels, namely an average of $35 \%$ of the median wage, compared with $61 \%$ in France (CERC document no. 101, 1991). Thus the vast majority of female part-timers have to accept the local minimum rate, since their lack of mobility often confines them to retail or service jobs in their immediate neighbourhoods.

Thus a section of the female labour force is confined to the periphery of the labour market by their family status. Although they are far from satisfied with the working conditions on offer to them, most of them do not seem to want to work full time because of their domestic responsibilities. Likewise, given that their status as "housewives" legitimates their position within the family and that they are "protected" by the dependency clause in the social security legislation, they only rarely seem to give voice to the feeling of vulnerability in the labour market that is widespread among their French counterparts, some of whom have to live with precariousness both at work and in the family. Thus comparison of the two employment surveys shows that $78 \%$ of the 2.21 million Japanese women looking for work would like a temporary or part-time job, whereas only $20 \%$ of the 1.58 million unemployed women in France are looking for temporary or part-time jobs as their first choice.

\section{II-3 Two types of family Convention}

These analyses of childcare arrangements and part-time work provide a basis for defining the nature of the "family convention" that has become established in each society.

In Japan, this "family convention" is characterised by the relative autonomy of the family as a reproductive sphere and therefore as a producer of domestic services. This characteristic reinforces the gender division of labour within the private space of the family; men have the responsibility of providing for their families financially, while women's main tasks are management of the household budget ${ }^{12}$ and domestic work. Women's labour market activity can only be understood by reference to this concept of the family. The Japanese state underpins the autonomy of the family and the role of "housewives" in three ways. The first is the absence of state intervention in the family, which is symbolised not only by the low level of spending on social security benefits (14.0\% of national income in Japan, compared with $33.7 \%$ in France in 1989) but also by the virtual absence of family allowances, which account for only $0.9 \%$ of social security benefits in Japan, compared with $8.2 \%$ in France. The second is the concept of the household, which is used by the state as a fiscal and social unit, which further reinforces the "dependent" status of wives. The third is the low level of state support for working mothers, which considerably reduces their chances of continuing their careers.

In contrast to the relative withdrawal of the state from the family sphere in Japan, the "family convention" in France, which would be inconceivable without the intervention of the state, is based on active interaction between government policies, the family and women (A. Pitrou 1995). The family is still a quintessentially private space and still produces most domestic services, which gives women prime responsibility for the management of domestic tasks. At the same time, however, it is the object of a great deal of state intervention, both as an institution of social reproduction and as a household - the basic economic unit. Using social transfers as its instrument, the state has put in place policies intended to encourage or support certain patterns of behaviour. As a result, family life is shaped by a range of measures in the social (family allowances), fiscal (the family quotient) and educational (childcare) spheres. Thus, in exchange for this state interference in the private sphere, women receive assistance in their capacity as mothers and protection in their capacity as workers (L. Hantrais and M.-T. Letablier 1995). It is against this general background that the multidimensional status of French women is forged, and it is this status that enables them to perform several roles, albeit at the cost of heavy workloads both at work and in the home (D. Anxo and A.M. Daune-Richard 1991). Although they are not immune from contradictions, these public policy measures are an integral part of the "family convention" that contributes to the construction of the female labour supply in France.

\footnotetext{
10 Unlike in France, where the labour code strictly defines the conditions under which fixed-term contracts can be drawn up, there are no restrictions in this respect in Japan. However, court decisions have given fixed-term contracts that have been tacitly renewed on several occasions the same standing as permanent contracts.

${ }^{11}$ These are average figures for women working part time: $2^{\text {nd }} 1996$ survey on part-time work, Ministry of Labour.

${ }^{12}$ It is the dominant practice in Japan for all household income, including inherited wealth, to be under the wife's control; this of course requires a certain degree of "professionality" on the part of married women.
} 
Nevertheless, these two forms of "family convention" are not immutable over time, despite the relative internal coherence of each one. They now face the general and specific tensions that affect every society. The Japanese "family convention", which is suffering particularly from demographic problems such as a declining birth rate and an ageing population, will see a gradual increase in the role of the state in promoting the autonomy of women both as mothers and as workers; the generalisation of "parental leave" and the attempt, in the name of gender equality, to abolish the "dependent" status that gives women who stay at home favourable treatment in the tax and social security regimes are only the first signs of change. Likewise, the French "family convention" has to confront the weakening of the traditional family ${ }^{13}$ and the crisis in the financing of the welfare state. In this general context of change, it is the capacity of the "family space" to create new rules that will be placed under increasing pressure.

\section{DIFFERENCES IN MALE AND FEMALE CAREER TRAJECTORIES}

Having analysed the links between the labour supply and the family, we will now turn to another analysis of the structuring of the occupational space, which will be approached in terms of the labour market. Obviously, these two dimensions of the analysis constitute the two, inseparable sides of the same coin. We will see how the careers of male and female employees diverge (if at all) over time in accordance with the nature of the "wage-labour convention" in force.

Without debating its basis, we will accept the classic notion of the internal labour market, which is generally made up of a hierarchy of jobs, points of entry to that hierarchy and clearly marked career trajectories. Above all, this internal labour market is seen as an occupational space in which efficiency (greater productive efficiency) and equity (greater predictability and stability in employees' lives) are produced through the stabilisation of the workforce, in contrast to the external labour market, where enforced or voluntary mobility are constantly required in order to regulate the market. This distinction between internal and external markets, however schematically presented here, enables us to shed light on the articulation of workforce management and gender relations in each society.

The hypothesis put forward here is that efficiency and equity are combined differently in France and Japan and that this produces two different forms of "wage-labour convention" which impact in their own unique ways on the construction of male and female career patterns.

\section{III - 1 The stabilisation of male and female employees in the internal labour market}

We will attempt to examine the role played by the internal labour market in the differentiation of male and female career trajectories by measuring the extent to which men and women are integrated into the firm. To this end, and using our samples of wage-earners as a basis (18.1 million in France and 46.6 million in Japan), we will first devise an indicator of mobility by calculating the share of mobile employees in a given age cohort and then construct an indicator of integration based on the share of non-mobile employees in a given age cohort.

Although they are very simple, these indicators (see appendix for the methodology) reveal certain characteristics common to the labour markets of the two countries (Table III). They are mechanical phenomena, such as the decline in mobility with age or the correlation of seniority with age, that underpin the structuring of internal labour markets in the two countries. In addition to these common characteristics, the indicators highlight differences in the organisation of the wageearning class, particularly in respect of the differentiation of male and female career patterns.

In France, each firm organises its internal labour market (regarded as a set of hierarchically structured jobs) by gradually integrating a significant proportion of its workforce. However, the vehicle for this integration is a fairly lengthy selection process that aims to match job profiles with the profiles of employees holding certain qualifications. In contrast to Japan, young people under 30 seem to be much less integrated into internal labour markets. This may reflect two contrasting realities. On the one hand, it is linked to the difficulties the least well-qualified young people experience in gaining access to the jobs that form the entry points into the internal labour market; since they tend to be employed in unstable jobs, in which spells of employment alternate with periods of unemployment, they are constantly being pushed back into the external labour market. On the other hand, it also reflects the manoeuvrings of economic agents in a occupational space in which strategic mobility plays an important role : young people with good educational or vocational qualifications seek to realise the value of those qualifications by adopting career strategies that include external mobility as one means of advancement.

${ }^{13}$ For example, $8.4 \%$ (1.29 million out of 15.27 million women aged between 20 and 60 ) of French women are living in single-parent families, compared with only 1.5\% (534,000 women aged between 20 and 60) of Japanese women (sources op. cit.). 
TABLE 3

INTERNAL LABOUR MARKET - EXTERNAL LABOUR MARKET .

France

\begin{tabular}{|c|c|c|c|c|c|c|c|c|c|c|}
\hline \multirow{3}{*}{$\begin{array}{l}\text { Age } \\
20-24\end{array}$} & \multicolumn{5}{|c|}{ FRENCH WOMEN } & \multicolumn{5}{|c|}{ FRENCH MEN } \\
\hline & \multirow{2}{*}{$\begin{array}{c}\text { Participation rate } \\
\\
54 \%\end{array}$} & \multicolumn{2}{|c|}{$\begin{array}{c}\text { No. of female employees (in } \\
\text { millions) }\end{array}$} & \multirow{2}{*}{$\begin{array}{c}\begin{array}{c}\% \text { of employees } \\
\text { integrated into ILM } \\
\text { (row \%) }\end{array} \\
25 \%\end{array}$} & \multirow{2}{*}{\begin{tabular}{|r|}
$\begin{array}{r}\% \text { of mobile } \\
\text { employees } \\
\text { (row \%) }\end{array}$ \\
$75 \%$
\end{tabular}} & \multirow{2}{*}{\begin{tabular}{|c|} 
Participation rate \\
$63 \%$ \\
\end{tabular}} & \multicolumn{2}{|c|}{ No. of male employees (in millions) } & \multirow{2}{*}{$\begin{array}{c}\begin{array}{c}\% \text { of employees } \\
\text { integrated into } \\
\text { ILM } \\
(\text { row } \%)\end{array} \\
25 \%\end{array}$} & \multirow{2}{*}{\begin{tabular}{|c|}
$\begin{array}{c}\% \text { of mobile } \\
\text { employees (row } \\
\% \text { ) }\end{array}$ \\
$75 \%$
\end{tabular}} \\
\hline & & 0.82 & $100 \%$ & & & & 0.87 & $100 \%$ & & \\
\hline $25-29$ & $81 \%$ & 1.34 & $100 \%$ & $33 \%$ & $43 \%$ & $95 \%$ & 1.60 & $100 \%$ & $32 \%$ & $44 \%$ \\
\hline $30-34$ & $78 \%$ & 1.27 & $100 \%$ & $60 \%$ & $27 \%$ & $97 \%$ & 1.62 & $100 \%$ & $59 \%$ & $26 \%$ \\
\hline $35-39$ & $78 \%$ & 1.28 & $100 \%$ & $53 \%$ & $21 \%$ & $97 \%$ & 1.58 & $100 \%$ & $55 \%$ & $19 \%$ \\
\hline $40-44$ & $77 \%$ & 1.29 & $100 \%$ & $45 \%$ & $17 \%$ & $97 \%$ & 1.60 & $100 \%$ & $51 \%$ & $15 \%$ \\
\hline $45-49$ & $76 \%$ & 1.00 & $100 \%$ & $36 \%$ & $15 \%$ & $96 \%$ & 1.27 & $100 \%$ & $45 \%$ & $13 \%$ \\
\hline $50-59$ & $56 \%$ & 1.07 & $100 \%$ & $40 \%$ & $10 \%$ & $80 \%$ & 1.50 & $100 \%$ & $55 \%$ & $8 \%$ \\
\hline
\end{tabular}

JAPAN

\begin{tabular}{|c|c|c|c|c|c|c|c|c|c|c|}
\hline & \multicolumn{5}{|c|}{ JAPANESE WOMEN } & \multicolumn{5}{|c|}{ JAPANESE MEN } \\
\hline Age & Participation rate & \multicolumn{2}{|c|}{$\begin{array}{l}\text { No. of female employees } \\
\text { (in millions) }\end{array}$} & \multirow{2}{*}{$\begin{array}{c}\begin{array}{c}\% \text { of employees } \\
\text { integrated into ILM } \\
\text { (row \%) }\end{array} \\
34 \% \\
\end{array}$} & \multirow{2}{*}{$\begin{array}{c}\begin{array}{c}\% \text { of mobile employees } \\
\text { (row \%) }\end{array} \\
66 \%\end{array}$} & \multirow{2}{*}{$\begin{array}{c}\text { Participation rate } \\
79 \% \\
\end{array}$} & \multicolumn{2}{|c|}{ No. of male employees (in millions) } & \multirow{2}{*}{\begin{tabular}{|c|c|}
$\begin{array}{c}\% \text { of employees } \\
\text { integrated into } \\
\text { ILM } \\
\text { (row } \%)\end{array}$ \\
$40 \%$ \\
\end{tabular}} & \multirow{2}{*}{\begin{tabular}{|c|}
$\begin{array}{c}\% \text { of mobile } \\
\text { employees (\% } \\
\text { row) }\end{array}$ \\
$60 \%$ \\
\end{tabular}} \\
\hline $20-24$ & $80 \%$ & 3.35 & $100 \%$ & & & & 3.40 & $100 \%$ & & \\
\hline $25-29$ & $69 \%$ & 2.34 & $100 \%$ & $43 \%$ & $36 \%$ & $97 \%$ & 3.72 & $100 \%$ & $51 \%$ & $25 \%$ \\
\hline $30-34$ & $60 \%$ & 1.69 & $100 \%$ & $50 \%$ & $35 \%$ & $98 \%$ & 3.46 & $100 \%$ & $77 \%$ & $13 \%$ \\
\hline $35-39$ & $71 \%$ & 2.02 & $100 \%$ & $33 \%$ & $35 \%$ & $98 \%$ & 3.52 & $100 \%$ & $69 \%$ & $10 \%$ \\
\hline $40-44$ & $78 \%$ & 2.98 & $100 \%$ & $22 \%$ & $31 \%$ & $98 \%$ & 4.44 & $100 \%$ & $67 \%$ & $7 \%$ \\
\hline $45-49$ & $77 \%$ & 2.46 & $100 \%$ & $17 \%$ & $22 \%$ & $98 \%$ & 3.61 & $100 \%$ & $64 \%$ & $6 \%$ \\
\hline $50-59$ & $67 \%$ & 3.56 & $100 \%$ & $26 \%$ & $16 \%$ & $97 \%$ & 6.09 & $100 \%$ & $66 \%$ & $8 \%$ \\
\hline
\end{tabular}

Sources : op. cit.
Note 1: Mobile employees (indicator of mobility) are those with less than 3 years' seniority Note 2: The definitions for integrated employees (indicator of integration) are as follows :
$20-24$ years $\rightarrow$ more than 3 years' seniority
25-29 years $\rightarrow$ more than 5 years' seniority
$40-44$ years $\rightarrow$ more than 15 years' seniority
$45-59$ years $\rightarrow$ more than 20 years' seniority
So

$35-39$ years - more than 10 years' seniority 
However, this period of transition is followed by a period of employment stabilisation that coincides with the familyraising phase. After the age of 35 , the risk of unemployment diminishes considerably, particularly among men, although a section of the labour force is condemned to permanent marginalisation on the periphery of the labour market. Moreover, flows into the external labour market diminish considerably, although neither strategic nor enforced mobility disappears altogether. At the same time, the share of employees in stable positions continues to rise. In the $40-44$ age group, $51 \%$ of men and $45 \%$ of women have more than fifteen years' seniority with their employers. Even though seniority is not always equated with high wage levels for French employees (Nohara 1995), the internal labour market does offer them protection against uncertainty and opportunities for promotion. In particular, the "administrative" form of job management that characterises internal labour markets in France objectifies the conditions of access to higher-level jobs and offers women some degree of protection against the "arbitrary" judgements of employers. ${ }^{14}$ This stabilisation is further consolidated beyond the age of 45 , although to a greater extent among men than among women, which suggests that some women of this age have had temporarily to interrupt their careers. Nevertheless, this general trend continues until the point at which retirement or early retirement leads to withdrawal from the labour market; for increasing numbers of people, this now takes place even before the age of 60 .

What is interesting from the point of view of comparisons between men and women is the relative similarity of their career trajectories in France, even though women here, as elsewhere, are characterised by a lower degree of "employability" than men. They are in fact more likely to become unemployed and to be in low-skill jobs or low-productivity sectors, which has a serious impact on their pay levels, as we shall see below. Despite this, women do not seem to be significantly more disadvantaged than men when it comes to advancement in internal labour markets. Combined with a range of institutional support mechanisms, it is the position that a significant proportion of women attain in internal labour markets that gives them a certain degree of continuity in their economic activity.

In Japan, male and female career trajectories diverge over time, except in the period immediately following the completion of education and subsequent entry into the labour market. Since the transition between education and work is institutionalised, firms take on young workers lacking any immediately operational skills. Thus young men and women alike experience little difficulty in entering the internal labour market, where the hierarchy is based on the classification of accumulated skills, and not on the job-based classification system that pertains in France. Selected initially for their "potential", i.e. their capacity to learn, they are then given the in-house training provided by each company. This intensive joint investment in the formation of human capital, which from the outset takes a long-term approach, has several important consequences for career development. Firstly, each company puts in place a payment system in which there is a high correlation between age and/or seniority and which is designed to retain the employees in whose training so much has been invested. Secondly, since the only opportunities for promotion are these offered by the internal labour market, employees' strategic behaviour is aimed at ensuring that they make their way steadily up the promotional ladder. Thirdly, in the absence of any accredited certification of the competencies acquired through company-specific training programmes, any move into the external labour market systematically disadvantages anyone leaving the internal market.

This principle of long-term joint investment which underlies the construction of the professional space and of professionality in Japan sharply differentiates men from women in the labour market. Highly integrated into the company from the outset, many men build their entire careers within the internal labour market. Although it is far from being realised in practice, the "lifetime employment" model, based on a working life spent within the same company from completion of education until compulsory retirement, is a normative influence not only in large firms but also in many smaller companies: $67 \%$ of male employees aged between 40 and 44 have more than 15 years' seniority (compared with $51 \%$ in France), and $64 \%$ of male employees aged between 45 and 49 have more than 20 years' seniority (compared with $45 \%$ in France). At the same time, this intensive structuring of internal labour markets, based on the apprenticeship principle, helps considerably to reduce the risks of insecurity or unemployment among prime-age males who are heads of households and to reinforce family and social stability, despite cyclical economic fluctuations.

On the other hand, women's careers develop in a very different way. Although they are hired by firms when they complete their education, young women are often confined to simple routine tasks that do not require much investment in training. Until recently, this treatment was justified to some extent by the generally lower level of educational qualification among women; however, such segregation is gradually losing its rationale, particularly in service industries, because of increasing qualificational levels among women. However, despite the introduction since 1986 of equal opportunities legislation, many women with the same qualifications as their male counterparts are still victims of occupational segregation,

\footnotetext{
14 It is worth noting that $31 \%$ of female employees in France work in non-market sectors influenced to varying degrees by public-sector management methods, compared with a little less than $14 \%$ in the case of Japan. The importance of these (quasi) public-sector internal labour markets has undoubtedly played a major role in the emergence of French women as serious players in the world of work.
} 
which severely reduces their promotion opportunities. Women account for approximately $10 \%$ of managerial and professional staff (cadres) in Japan, compared with 23\% in France (Employment surveys, op. cit.).

Coupled with this demotivating work environment, women also encounter difficulties within the family and the wider society in pursuing their careers when they marry. Although marriage is no longer the principal cause of their withdrawal from the labour market, many women finish by leaving their jobs in the child-bearing years, around the age of 30 . For most women, therefore, the years between 30 and 34 constitute a real turning point, a period of transition from full-time employment to the life of a married women dividing her time between family responsibilities and temporary or part-time work. Between the ages of 30 and 44 in particular, they are forced back to the margins of the external labour market, where they can be mobilised to move in and out of atypical jobs in accordance with cyclical fluctuations in the economy. Only a minority of them retain their jobs in the internal labour market : $22 \%$ of Japanese women aged between 40 and 44 have more than 15 years' seniority compared with $67 \%$ of Japanese men of the same age and $45 \%$ of French women in the same age group.

Given their social environment, this decision partially to withdraw from the labour market that is often forced upon married women when they start a family is not incompatible with rational economic behaviour at the household level. Moreover, according to some surveys ${ }^{15}$, it would seem to be approved by many of the women concerned. Thus the "secondary" status associated with part-time work proves to be widely accepted in the name of balancing family responsibilities and paid work.

Nevertheless, tensions become apparent when women became available for work again as they gradually free themselves from their day-to-day responsibilities for childcare. Over the age of 45 , a diversity of attitudes among women emerges: some continue to be satisfied with their status for positive reasons (in order to retain their autonomy etc.) or for negative reasons (care of elderly parents, lack of opportunities), while increasing numbers of generally more highly qualified women are eager to return to work, although their exclusion from internal labour markets confines them to a marginalised position in the labour market. This situation, which is aggravated in Japan by the absence of objective qualification criteria, undeniably causes problems. As a result, it will be essential to make at least partial modifications to the "family and wagelabour conventions" currently in force, particularly since these women will have many years of active life in front of them after having raised their children thanks to the remarkable increase in their life expectancy.

\section{III-2 Disparities in men's and women's pay over their life cycles}

With this in mind, we will briefly survey gender wage curves. Since wage in France and Japan has been already been the subject of a thorough comparative investigation in our earlier econometric studies (Nohara 1995), we will limit ourselves here to outlining some of the differences between men's and women's pay (Figure III). ${ }^{16}$

\section{FIGURE III - Pay curves by age}
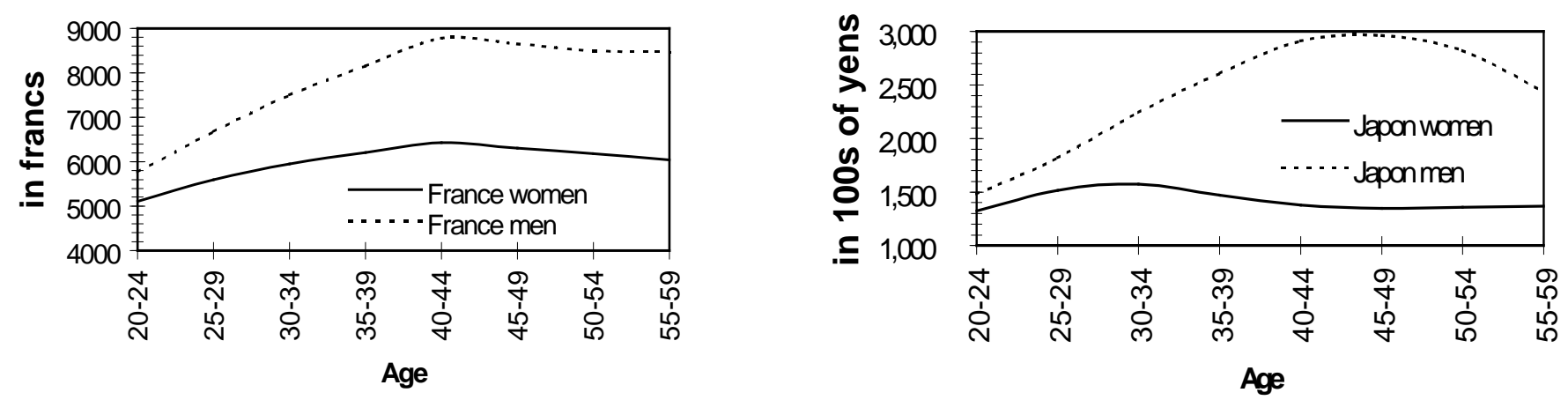

Although the trend is downwards, pay discrimination against women is still a general phenomenon in all countries. However, many empirical studies show that the disparity in pay between men and women differs quite considerably from one

\footnotetext{
15 The economic planning agency conducts periodic opinion polls among women on their life cycle; the findings of these surveys suggest that two thirds of women prefer to interrupt their careers in the child-bearing years followed by a return to work, while only $14 \%$ of them consider continuous labour market participation to be the ideal model (1989).

${ }^{16}$ Our statistical sources are the "wage structure surveys" conducted in each country in 1986 among firms with more than 10 peoples. These national surveys used very similar data-gathering methods and the same sample field, covering full-time, permanent employees.
} 
country to another. As it happens, it is much more marked in Japan than in France; median female pay in France is $77 \%$ of median male pay, compared with only $58 \%$ in Japan. ${ }^{17}$

This pay phenomenon arises of course out of the interaction of a whole set of factors and mechanisms. According to neo-classical theory, which emphasises personal choice, it reflects differences in individual characteristics, such as educational level, work experience etc. (G. Becker 1962). Structuralist theories attribute such disparities to the segmentation of the occupational areas in which men and women operate as economic actors (M. Reich, D.M. Gordon, R.C. Edwards 1978). For internal labour market theorists (P. Doeringer, M. Piore 1971), who encompass these two explanations without distinguishing between them, it is career patterns that seem to the decisive factor in structuring the disparities in men's and women's pay. From the point of view of societal analysis, which, over and above universal principles, takes seriously national differences in observed phenomena, it is important to identify two sets of internally coherent mechanisms within which, despite everything, the male/female disparity is legitimated. The approach outlined here will be based on an examination of the notion of "wage equity", in which it will be regarded as an outcome of the "wage-labour convention" which, in any given society, involves a complex interaction between various social, economic and institutional mechanisms.

In France, men's and women's pay evolves with age in fairly similar ways. As workers pass through the various phases of the life cycle, their pay increases, although the extent of such increases varies with sex, formal qualifications and skills. Nevertheless, this general similarity conceals a sharply defined fault-line, denoting the distinction between manager( cadre ) and "executant"( non-cadre ), that runs through both the male and female populations. This fault-line, which finds material expression in the considerable pay gap between the top and bottom of the hierarchy, reflects two separate mechanisms of pay determination.

In the "executant" category (manual and lower white-collar workers), to which most women belong, rising pay tends to be linked with seniority, i.e. the position workers acquire over time within the internal labour market. This explains why many women, particularly those without formal qualifications, are reluctant to take a career break. The various arrangements put in place by the state to support working mothers may well have their origins in the reality of women's position in the labour market.

In the managerial category (technicians, engineers and cadres), it is qualificational level and age - regarded as an indicator of professional experience - that determine pay. Since these indicators have a general value, and are therefore transferable, they enable those in possession of them to engage in strategic behaviour, including external mobility, irrespective of their personal attributes. Once acquired, they afford women a certain degree of protection against the risks of downgrading.

These two mechanisms are supplemented by a third, more institutional one, namely the minimum wage system. Set at a fairly high level (61\% of the median wage), this minimum wage helps to bolster the wages of unskilled workers, particularly women, although at the price of reducing the employability of those women furthest removed from the labour market.

In essence, these three mechanisms each constitute one element in the French "wage-labour convention". In fact, they reflect the use of referential rules derived from the classification system that characterises the "occupational space" in France. In this sense, the notion of "wage equity" is produced by the interaction between the occupational space and the "wage-labour convention". It is based in essence on the match between a particular job or function located within the classification system and skill, indicated through seniority, formal qualifications or professional experience. A convention of this kind, based on the principle of "equal pay for equal work", seems better able to contain the disparity in pay between the two sexes without for all that succeeding in neutralising the negative effects of the various handicaps that French women accumulate, relative to men, over the course of their life cycle.

In the case of Japan, wage curves for men and women are completely different. Women's pay is positively correlated with seniority, whereas it remains insensitive to age; women's pay stagnates or even declines after the peak achieved around the age of 30. Men's pay, in contrast, increases steadily over the life cycle; men's pay doubles on average between the beginning and end of their careers, whatever their occupational situation. This increase is very considerable compared with France, where men's pay increases by only $50 \%$ in the course of their careers. Clearly this rise in pay cannot be attributed solely to an age effect. It arises out of a positive interaction between age and seniority, as is shown by the extent to which Japanese men are integrated into firms' internal labour markets (Table III). Thus this positive interaction between the two variables, which serves to minimise the effect of formal qualifications (in contrast to France), creates a situation that is difficult to interpret in terms of the theoretical dichotomy of general/specific human capital. In order to

17 The median monthly wage is 5,905 francs for women and 7,627 francs for men in France, compared with 135,300 yen for women and 231,700 yen for men in France (sources, op. cit.). 
understand the Japanese situation, we have already analysed in earlier studies the process through which "wage equity" in Japan, symbolised by the concept of "lifetime pay", has, nevertheless, crystallised around the criterion of age.

This analysis revealed a Japanese form of "wage-labour convention " that might be described as the "social management of age"; it is regulated by two main mechanisms.

The first mechanism concerns the way in which the construction of skill and recognition of its worth are organised. Institutions in Japan have never succeeded either in putting a value on occupational skills or in producing a system of certification for such skills, except in the case of a few regulated professions. Of course the range of qualifications produced in the school and university hierarchy classifies young people on the basis of general educational level and hence of their "potential". However, companies then put them through a lengthy on-the-job learning process, which ultimately cancels out to some extent the "signalling effect "of their formal qualifications, in contrast to what happens in France. The vast majority of employees convert their "potential" into actual productive capacity by gradually taking on the various tasks to be performed in the companies for which they work. This accumulation of hybrid and tacit knowledge - which is difficult to transfer because it is not socially objectified - underpins the construction of professionality and career. The increase in wage with age is the means whereby this learning process is validated.

The second mechanism relates to the legitimacy of the concept of "lifetime pay", which has been championed by the unions for half a century and reflects the incorporation into direct wages of certain consumption needs acknowledged as essential. Given the low level of social transfers (14\% of GNP in Japan, compared with 34\% in France in 1989), labour force reproduction costs tend to be borne more directly by individual employees or households. The "lifetime wage", which goes hand in hand with "lifetime employment", is intended to meet the increased consumption needs (due to increased family responsibilities) that workers have to satisfy as they pass through the various phases of the life cycle.

This "wage-labour convention", which is embedded in the "occupational space" in Japan, determines the organisation of the wage-earning class through the positive and negative interactions that occur between age and seniority or age and sex, which creates a form of internal market considerably at variance with that found in France. Two phenomena in particular symbolise Japanese specificity in this respect.

Firstly, the Japanese "wage-labour convention " tends to flatten the male pay hierarchy by reducing disparities in pay caused by differences in occupational situation. In particular, the wage disparities between the various levels of formal qualification and socio-occupational categories are minimised by age effects : for example, young graduates with 4 or 6 years' higher education start on a salary that is $40 \%$ less than that of experienced, prime-age male manual workers.

Secondly, it considerably intensifies wage discrimination against women, particularly married women. Thus pay differentials between men and women, which are narrow at the outset, widen consistently after the age at which women marry and have children. As we have seen, these differentials arise mainly from women's loss of occupational status following their withdrawal from the labour market for family reasons. Women return to work either on atypical contracts or in the most vulnerable productive sphere. Thus the principle of the social management of age sanctions the sexual distribution of status between male "heads of household", who are the main providers of financial resources, and "housewives", whose financial contribution is regarded as a supplementary income. Thus the "lifetime wage" for men goes hand in hand with the "secondary income" earned by married women. In the Japanese occupational space, where a job is not a yardstick by which pay is determined (unlike in France), the difference in social and family statuses tends to reinforce wage inequalities.

\section{CONCLUSION}

The approach developed here, which draws its inspiration from societal analysis, led us from the outset to locate women in their societal dimension, i.e. in their interdependence with men. In this way, the notion of society acquires a significance that it does not have in those studies that isolate gender and treat it as a simple variable, thereby failing to place it in a social context. As a result, we have been able to go beyond the mere listing of numerous factual differences to outline the overall configuration of the relationships between men and women, which differs considerably from one country to another.

Combined with the theoretical stance of "non-comparability", the societal contextualisation of observed phenomena makes it possible to integrate the macro and micro levels, to avoid a "functionalist" equivalence between the two and to go beyond a "universalising" vision. Similarly, the inductive methodology adopted is shown to possess considerable analytical strength even in areas not previously investigated in any depth by the societal school. The societal regulation of gender relations has not explicitly formed part of its sphere of analysis, except in a few statistical studies of wage inequality comparing France and Germany and France and Japan (Nohara and Silvestre 1987). The initial empirical research that 
formed the basis for the societal school was conducted in the 1970s and, given the historical context of that decade, it is hardly surprising that the research focused on the largely male workforce in large manufacturing firms that symbolised the national economy at the time.

However, these historical contingencies do not negate the significance of the principal analytical categories thus revealed. Once adjusted (enriched even) to take account of the diversity of subjects or levels selected for analysis, they can be deployed to investigate a wide range of social phenomena. Likewise, the notion of societal coherence, which has often been hastily criticised as "static", a-historical and tending merely to reproduce social phenomena, retains its relevance if it is understood as the form in which social relationships (including conflicts, contradictions and "negative" legitimacy) crystallise at a given point in time and as the sole point of departure from which a society can begin to devise its own future. The notion then turns out to be very closely related to the dynamic notion of "routine", which marks out the "path dependency" in the evolutionary literature, or that of the "irreversibility" of mental configurations which, after each period of learning, restricts the field of possible choices because of the very nature of the knowledge internalised by the actor.

This comparison of the articulation of male and female economic activity in France and Japan has revealed a form of coherence unique to each society in the way in which production and social reproduction are regulated. However, such societal specificity does not exclude the existence of general mechanisms. On the contrary, each societal mode of regulating gender relations seems to be based on the interaction between the "occupational space" and the "family space". The former is linked directly to the "qualificational space", which was used in the Franco-German comparison and denotes the sphere in which the process of socialisation spreads out to encompass a set of rules and practices. The "family space", on the other hand, introduced here for the first time, denotes the sphere in which the familial division of labour is defined through interactions not only between individuals but also between those individuals, the wider society and the State. The actors are defined by, or emerge out of the strong interdependent relationships that these two spaces produce and maintain. The emphasis placed on interdependence reflects the urgent need to understand the intertwinement of the principles regulating the world of work and that of the family, particularly for the light such an understanding can throw on the production of the female labour supply. In emphasising this interdependence between work and the family, we are rejecting one of the basic principles of neo-classical economics, namely that the functions of supply and demand do not interfere with each other. Rejection of this principle opens up fertile terrain for interdisciplinary research on the boundaries between economics and sociology.

In order to move from the general to the specific, we have incorporated an intermediate category of analysis. This is reflected in the use of the notion of "convention", which denotes a form of agreement or, in other words, a societal capacity to keep under control the various rules, positions and interests that are both complementary and conflictive. The strength and legitimacy of such a "convention" are of course all the stronger the longer the period over which it can be sustained: a firmly implanted convention may even lead to the building-up of social " routine ". However, this does not prevent the "convention" from being slowly reconstituted as the arrangements put in place by the various actors evolve. Thus the "convention" is a tool that makes it possible to conceptualise the gradual movement through time between immobility and versatility. Similarly, it is also a tool for interpreting the sets of principles that regulate the various social spaces. The "occupational space" produces the "wage-labour convention", which governs the construction of the substantive or referential rules that regulate the recognition of skill, remuneration, mobility, etc. The "family space" produces the "family convention", which governs the practices, behaviour and perceptions surrounding the prevailing model of the family. The actual configuration of gender relations in a given society, such as those described in France and Japan, can only be analysed through serious examination of the complex but very real interlocking relationship between the "wage-labour convention" and the "family convention".

To conclude, let us list some of the benefits that may accrue to societal analysis through the introduction of an intermediate analytical category, such as the notion of " convention".

Firstly, it will make it possible explicitly to incorporate into our analyses the State, which is omnipresent behind the various education and family policies etc., as one of the actors that contribute to the construction of the convention, all of whom of course have their limited rationality.

Secondly, the "convention", understood as a cognitive device, can easily be made to incorporate the system of representations and values. It will enrich the cognitive dimension of societal analysis in such a way that concepts such as "dependence", "equity", "trust", "commitment" etc. can be more closely linked to analysis of the actor and of the interactions between actors.

Finally, each "space", endowed with a different kind of "convention", incorporates its own temporality. In this case, societal coherence, based on the composition of "spaces", faces a permanent risk of disequilibrium caused by differences in temporality. Ultimately, it is this perpetual process of rebalancing that gives societal coherence its dynamic. 


\section{BIBLIOGRAPHY}

ANXO, D et DAUNE-RICHARD, A-M(1991) : La Place Relative des Hommes et des Femmes sur le Marché du Travail : Une Comparaison en France et en Suède. In : Travail et Emploi Nº47. P.63-78.

BARRERE-MAURISSON, M-A(1992) : La Division Familiale du Travail. La Vie en Double. Presse Universitaire de France : Paris.

Vol.70. P.9-49.

BECKER, G (1962) : Investment in Human Capital : A Theoretical Analysis. In : Journal of Political Economy,

BECKER, G (1964) : A Theory of The Allocation of Time. In Economic Journal, Vol.75. P.493-517.

BENOIT-GUILBOT, O(1987) : Les Structures Sociales du Chômage en France et en Grande-Bretagne, Influences

Sociétales. In : Sociologie du Travail N²-87, p.219-236.

DAUNE-RICHARD, A-M(1993) : Activité et Emploi des Femmes : Des Constructions Sociétales Différentes en

France, au Royaume-Uni et en Suède. In : Sociétés Contemporaines Nº16. P.125-143. Lexington.

DOERINGER, P and PIORE, M(1971) : Internal Labor Markets and Manpower Analysis. Heath Lexington Books.

HANTRAIS, L et LETABLIER, M-T (éd.)(1995) : La Relation Famille-Emploi : Une Comparaison des Modes

d'Ajustement en Europe. Centre d'Etude de l'Emploi , Dossier Nํ․ Paris.

MAURICE M, SELLIER F et SILVESTRE J-J(1986) : The Social Foundations of Industrial Power : A Comparaison of France and Germany. The MIT Press, Combridge.

NOHARA, H et SILVESTRE, J-J(1986) : Industrial Structures, Employment Trends and The Economic Crisis : The

Case of France and Japon in the 1970s. In : Tarling, G (éd.) : Flexibility in The Labor Markets. Academic Press. London.

NOHARA, H(1995) : Les Salaires en France et au Japon : Comparaison des Structures de Salaires dans l'Industrie Manufacturière des Deux Pays de 1978 à 1986. In : Travail et Emploi №62. P.59-71. Paris.

PITROU, A(1995) : Les Politiques Familiales : Approches Sociologiques. Syros. Paris.

SELLIER, F(1984) : La Confrontation Sociale en France 1936-1981. Presse Universitaire de France. Paris.

\section{APPENDIX 1}

These indicators are both constructed by combining the variables of age and seniority: the first indicator, termed the mobility indicator, counts all those individual in each age group with less than 3 years' seniority in the firm. The indicator reflects the impact of the external market on careers. The second indicator, termed the integration indicator, reflects the importance of the internal market for careers. For any given age group, it measures the percentage of individuals whose seniority exceeds a certain threshold in such a way that it is reasonable to assume that a large part of their career has been spent in the same firm. This indicator is constructed on the basis of the following series of correspondences between age and seniority:

- For the $20-24$ age group, $\%$ of individuals with more than 3 years' seniority

- For the $25-29$ age group, $\%$ of individuals with more than 5 years' seniority

- For the 30-34 age group, $\%$ of individuals with more than 5 years' seniority

- For the $35-39$ age group, $\%$ of individuals with more than 10 years' seniority

- For the $40-44$ age group, $\%$ of individuals with more than 15 years' seniority

- For the $45-49$ age group, $\%$ of individuals with more than 20 years' seniority

- For the $50-59$ age group, $\%$ of individuals with more than 20 years seniority 